\begin{tabular}{|c|c|}
\hline \multirow{3}{*}{ 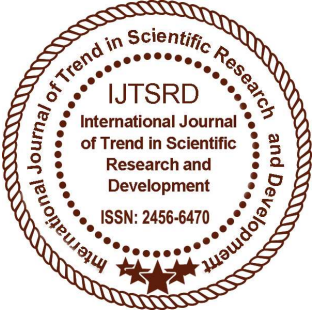 } & $\begin{array}{l}\text { International Journal of Trend in Scientific } \\
\text { Research and Development (IJTSRD) }\end{array}$ \\
\hline & International Open Access Journal \\
\hline & ISSN No: 2456 - 6470 | www.ijtsrd.com | Volume - 2 | Issue - 4 \\
\hline
\end{tabular}

\title{
A Case Study of Traumatic Wound Treated with Jatyadi Ghrita
}

\author{
${ }^{1}$ Kumar Rajeev, ${ }^{2}$ Sharma P. K, ${ }^{3}$ Gupta A. K \\ ${ }^{1}$ Assistant Professor, Department of Shalya Tantra, \\ Patanjali Bhartiya Ayurvigyan Evam Anusandhan Sansthan, Haridwar, Uttarakhand, India \\ ${ }^{2,3}$ Professor, Department of Shalya Tantra, Rishikul Campus Haridwar \\ Uttarakhand Ayurved University Uttarakhand, India
}

\section{ABSTRACT}

Initial treatment of wound aims to prevent infection and early wound healing.

Various treatment modalities are used for dressing of wounds keeping in mind good cosmetic outcome. Vagbhatta Acharya has also mentioned the effective treatment of Jatyadi ghrita in the management of wounds, painful ulcers, insect bite wounds, wounds caused by heat or fire and deep wounds by external application. In this context, Jatyadi ghrita application was carried out in the management of wound. The patient received in Shalya Tantra department of Patanjali Ayurved Hospital Haridwar Uttarakhand India and has been treated with Jatyadi ghrita. The patient recovered well with complete healing of the wound within span of 5 weeks.

\section{Keywords: Wound, Jatyadi ghrita}

Wound healing is replacement of destroyed tissues by living tissues. In secondary intention of wound healing, wound is closed by reepithelization and contraction with some deposition of scar tissue. The effective use of jatyadi ghrita in the management of wound is taken as ghrita is vrana ropaka (wound healing) and healing process was observed.

\section{CASE REPORT}

A male patient of 16 years age came to the shalya tantra opd with complaints of non healing wound of left hand. Patient was having pain and multiple lacerated, sloughy wound in anterior and posterior view of hand.
PAST HISTORY: Patient not a k/c/o DM, HTN or any other medical illness. He had two week history of injury of his hand in sugarcane juicer machine. He took treatment from some trauma centre where he is adviced to go for plastic surgery for complete recovery of hand. On examination there was open untidy wound with slough formation with multiple abrasion in hand. Also there was black gangrenous lower edge of wound. No purulent discharge was seen from wound.

TREATMENT GIVEN: Debridement was done and all the sloughy and necrosed part was excised. Triphala kwath was used to wash the wound followed by dressing with application of jatyadi ghrita gauze covering over the wound once daily. Oral medications Triphala gugglu, Arogyavardhani vati, Amalki rasayan were taken regularly. Wound was observed for its healing process under following criteria.
$>$ Edema around wound
$>$ Discharge from wound
$>$ Granulation tissue.

\section{OBSERVATIONS:}

ON $5^{\text {th }}$ day, wound was devoid of slough. Redness and tenderness was present. Edema present. On 10th day, the wound was bright red in colour and signs of epithelialisation at margins. On 15th day, healthy granulation tissue was present. 
Daily dressing was continued up to 5 week and epithelialisation of wound was covered within 5 weeks. The colour of epithelialisation resembled with surrounding skin.

\section{DISCUSSION}

Wound requires important conditions to be maintained :- prevention of infection and slough formation, maintenance of red granulation tissue. Probable Mechanism of action of Jatyadi ghrita and its practical use:-

The shodana and ropana contents in Jatyadi ghrita drugs found very efficacious as described in ancient classics. The action of tikta rasa is rakta prasadaka (blood purifier), ushna veerya is shothahara, ushna and teekshna are krimighna in nature, action on tridoshas as calms as Pitta. Shodana drugs on topical application reduce pain, discharge and oedema of the surrounding tissue. Initially drugs acts as a debriding agent, removing slough and necrotic material from wound and subsequently promotes smooth and uncomplicated healing. They reduce wound infection due to their bactericidal action on drug. The dressing soaked with shodhana drugs provides moist environment which enhances epithelialisation, prevent scales formation, beneficial in infected wounds with drug resistant bacteria.

The content Katuka improves reepithelialisation, neovascularisation and migration of endothelial cells and fibroblasts into the wound bed5. The jati patola and sikta have Vrana ropana action. Ghrita prevents fluid loss from burn wound and also lubricates surface of wound. Ghrita is having vrana ropana (healing) and kantivardhana (improving lustre) property so it helps in early healing with good pigmentation.

\section{CONCLUSION}

This case study reveals that wound dressing with Jatyadi ghrita produces good and faster wound healing. Also it can help in minimising post healing complications like hypopigmentation or hyperpigmentation.

FIGURES:-

Wound of left hand before, during and after treatment
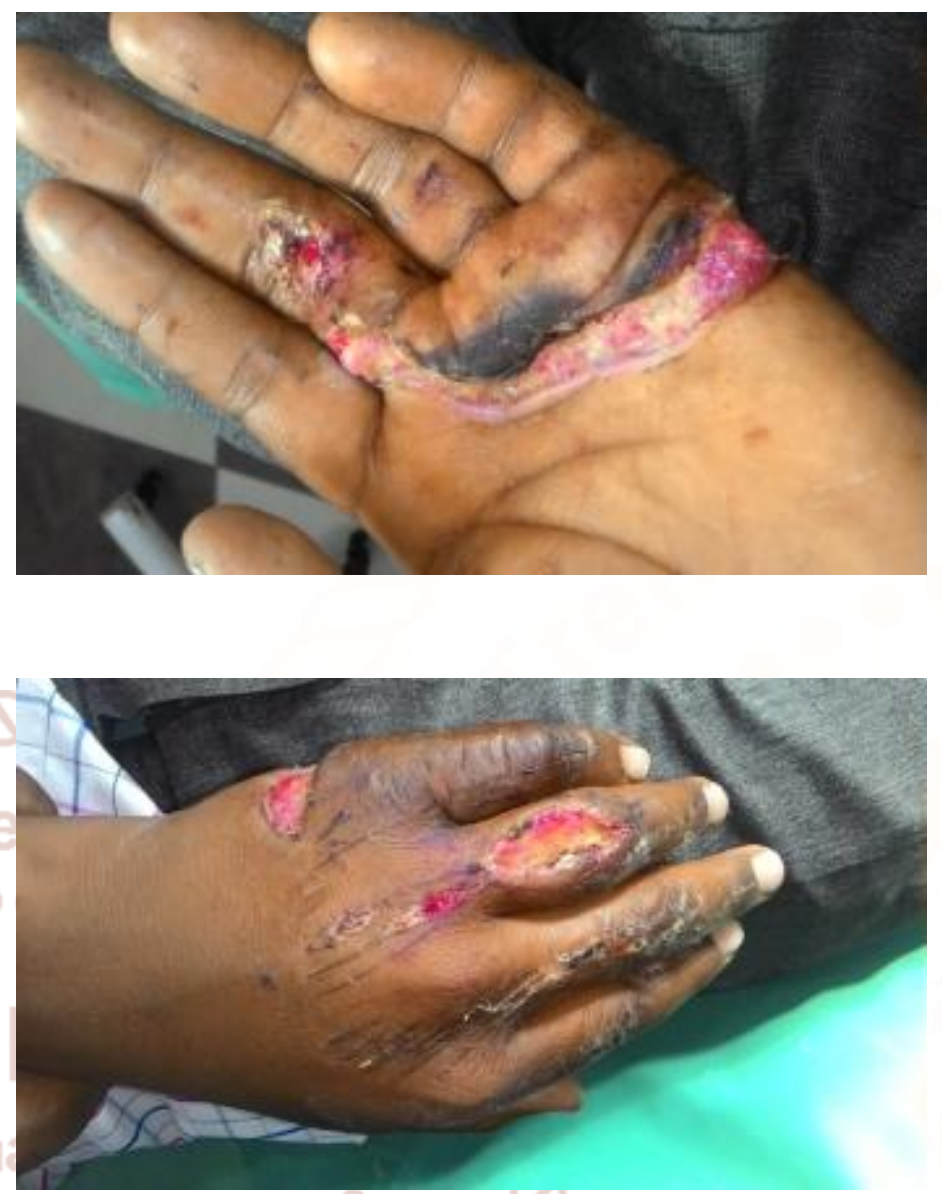

\section{BEFORE TREATMENT}
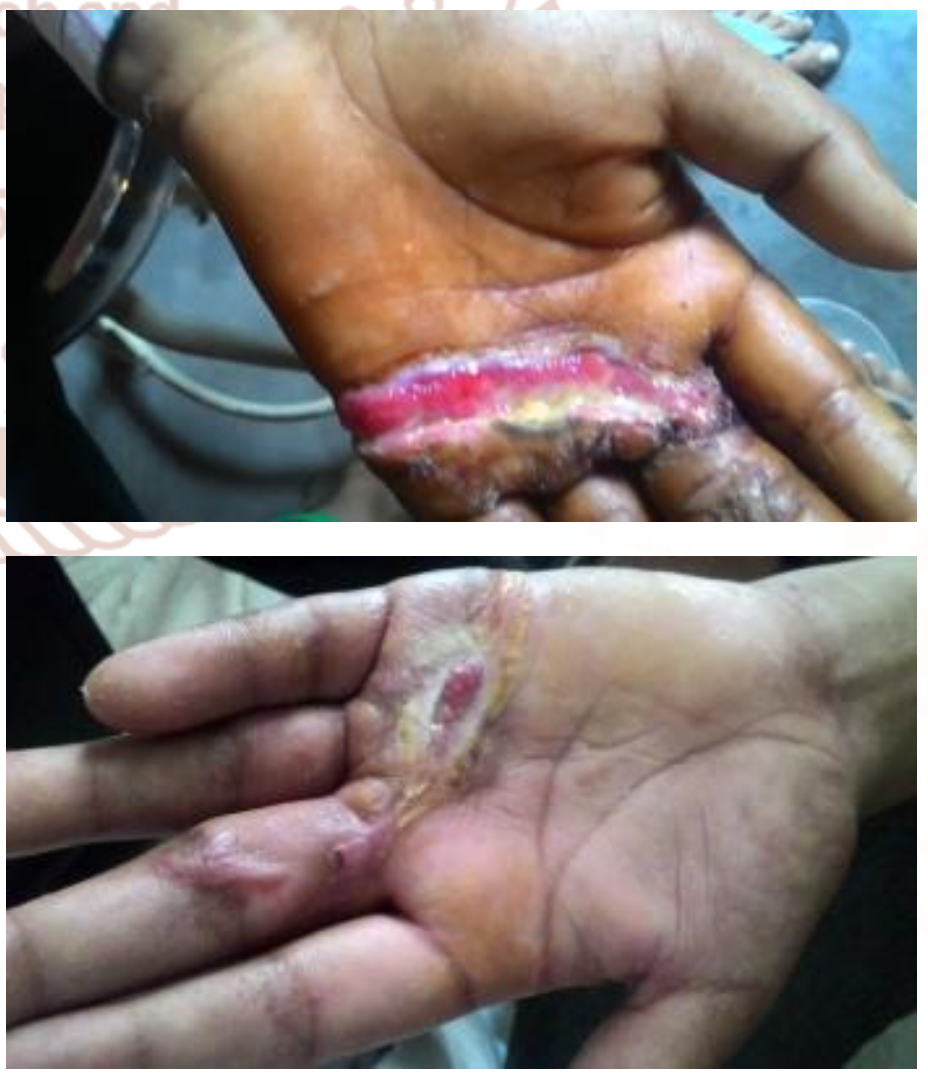

DURING TREATMENT 
International Journal of Trend in Scientific Research and Development (IJTSRD) ISSN: 2456-6470
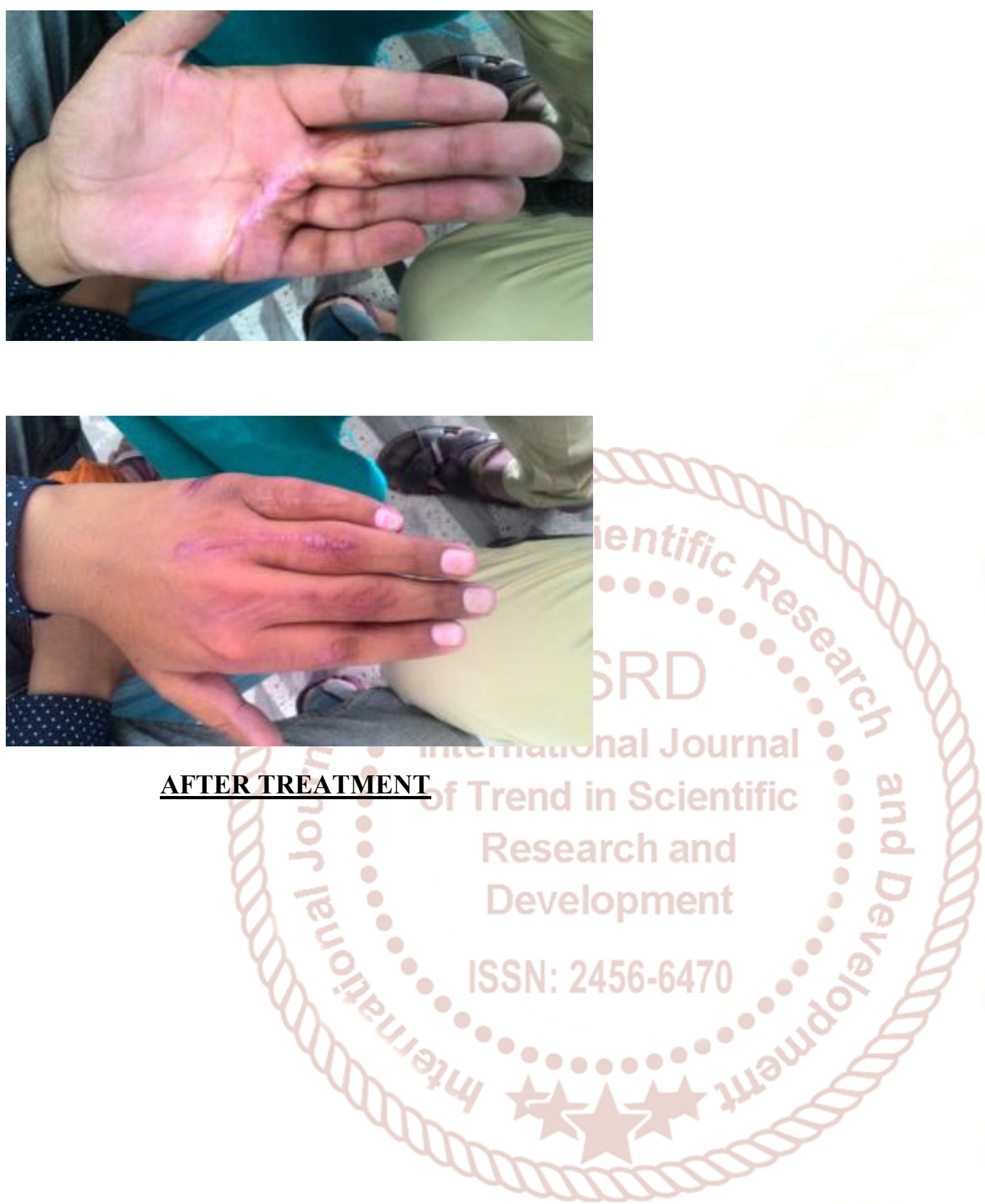